Document downloaded from:

http://hdl.handle.net/10251/158946

This paper must be cited as:

Albalat-Mascarell, A.; Carrió-Pastor, ML. (2019). Self-representation in political campaign talk: A functional metadiscourse approach to self-mentions in televised presidential debates. Journal of Pragmatics. 147:86-99. https://doi.org/10.1016/j.pragma.2019.05.011

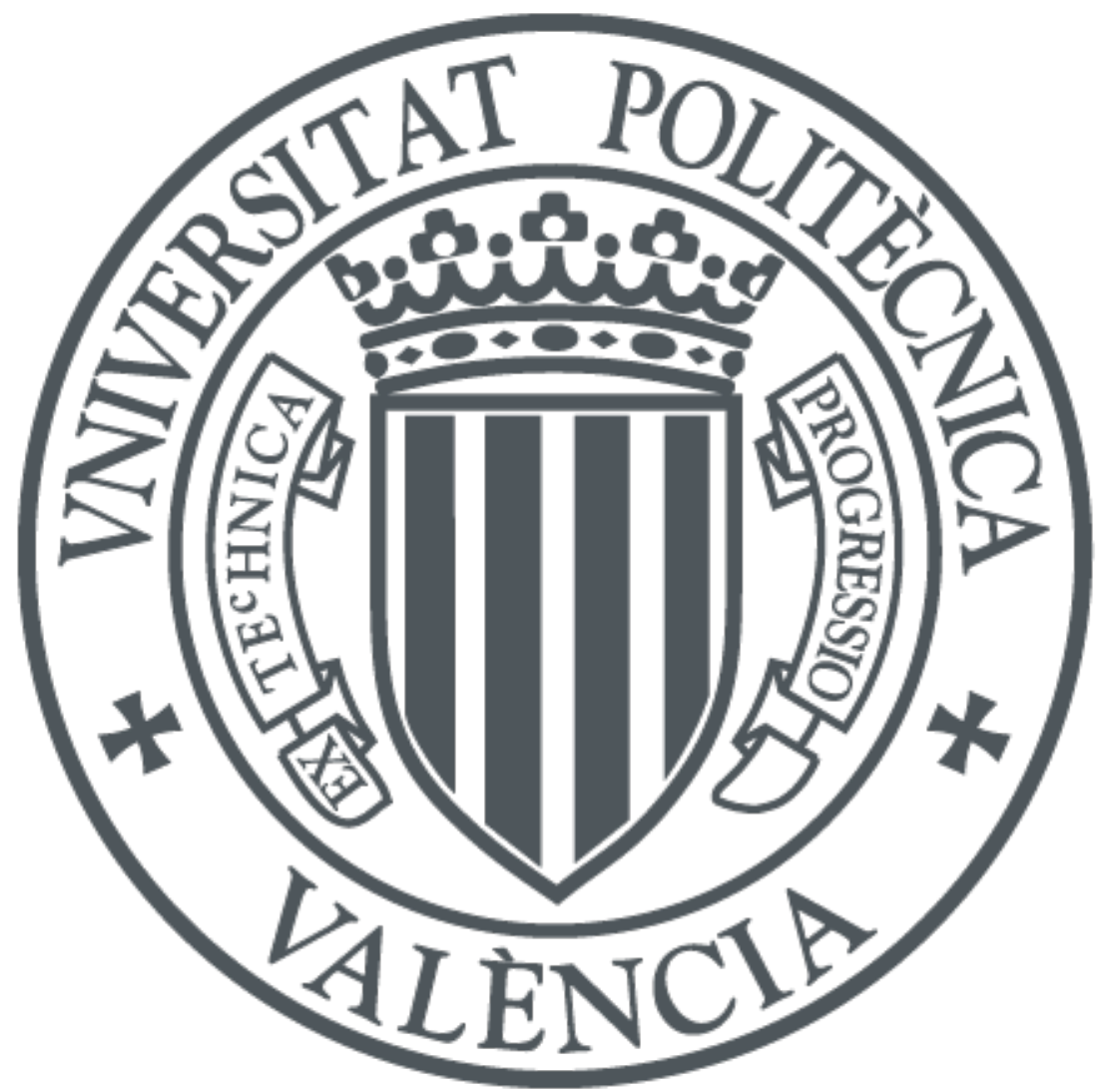

The final publication is available at

https://doi.org/10.1016/j.pragma.2019.05.011

Copyright Elsevier

Additional Information 


\title{
Self-representation in political campaign talk: a functional metadiscourse approach to self-mentions in televised presidential debates
}

\author{
Ana Albalat-Mascarell \\ María Luisa Carrió-Pastor \\ Universitat Politècnica de València
}

\begin{abstract}
Self-mentions (i.e., first person pronouns and self-citations) have proven to be one of the most powerful ways of rhetorical self-projection in academic discourse and their role in the construction of a self that engenders credibility in more overtly persuasive genres, such as political debates, has been extensively studied, given the vast literature on pronouns in political discourse analysis and specifically on their uses in political debates. To gain a better insight into the ways in which politicians can build a credible ethos through a competent and authoritative presentation of themselves in electoral debates, this paper compares the frequency and rhetorical roles of the self-mentions used by the candidates of the two major political parties (i.e., Democrats and Republicans) during the debates held for the United States presidential election of 2016. The Republican candidates (i.e., Trump and Pence) were found to make a notably greater use of selfmentions than their Democratic counterparts (i.e., Clinton and Kaine). Significant differences were also found in the rhetorical roles most commonly adopted by each politician to convey authority through the use of exclusive pronouns and self-citations.
\end{abstract}

\section{Introduction}

A key component of persuasion is the ability of speakers and writers to establish a positive representation of themselves, lending credibility to their arguments. For those entering the political arena, this is not without its difficulties as politicians and their teams of ghost writers or "spin doctors" (Wodak, 2009: 2, as cited in Reyes, 2015: 58) must not only provide their audience with reasons and factual evidence of the logical truth of their statements, but also with convincing proof of the speaker's professional competence and personal integrity. They must therefore shift attention to one of the central elements underlying persuasive discourse since the time of ancient Greece: ethos or the rhetorical appeal to the character and authority of the speaker (Kennedy, 1991; Murphy et al., 2014). In line with Maingueneau (2007), Amossy (2010), Roitman (2014) and others, the notion of ethos is primarily framed here as a discursive phenomenon consisting of any form of explicit expression which assists speakers in enhancing the credibility of their message in a given context. This persuasive objective can be accomplished through a range of linguistic and metadiscourse expressions (Hyland, 2005), but most directly through "self- 
mentions", i.e., exclusive first person pronouns, self-citations, and self-referential terms that make reference to the speaker (Hyland, 2001: 211; Hyland, 2005: 53).

The power of personal pronouns in political talk has been extensively analyzed in the literature taking into account their rhetorical functions by several researchers such as Wilson (1990), Zupnik (1994), De Fina (1995), Leudar, Masland and Nekvapil (2004), Fetzer and Bull (2008), Proctor and Su (2011), Boyd (2013), Pavlidou (2014), Roitman (2014), and Ivanova (2016). For instance, Zupnik (1994) focused on the use of vague deixis and its persuasive functions; De Fina (1995) analyzed the concept of speaker involvement and the pragmatic implications of pronominal choice in political discourse; Fetzer and Bull (2008) investigated the dependence of the choice of pronouns in political interviews; Proctor and Su (2011) studied the employment of pronominal choice to evoke nationalistic emotions and achieve one's career goals; and recently Ivanova (2016) focused on the way deictic references are employed in political domain to define rhetorical space. More significantly, Roitman (2014) even went as far as to investigate the relationship between the construction of a credible ethos and the different functions of the pronoun $I$ in a political debate. To our knowledge, however, no study so far has analyzed how politicians make use of the whole range of self-referential expressions which Hyland (2001) labels as self-mentions (i.e., all singular and plural first person pronouns and possessives referred to the speaker, together with self-citations and selfreferential expressions), least of all from a rhetorical perspective that encompasses both functional and metadiscoursal approaches to the building of an effective ethos and its appeal to the audience's emotions, or pathos (Amossy, 2000, 2010; Hyland, 2005).

Metadiscourse has recently been defined as "the ways in which writers and speakers interact through their use of language with readers and listeners" (Hyland, 2017: 16), and its role in revealing how discourse is rhetorically construed in a range of domains and genres is now well established (see e.g., Dafouz-Milne's (2008) metadiscourse research on newspaper opinion columns, Vasquez's (2015) analysis of metadiscourse strategies in online consumer reviews, Moya and Carrió-Pastor's (2018a; 2018b; 2018c) study of metadiscourse devices in digital comments on news or Carrió-Pastor's (2019) research that focuses on the analysis of business e-mails). Nonetheless, the bulk of the work on metadiscourse has centered on academic writing (e.g., Hyland, 2005; Ädel, 2006; Gillaerts and Van de Velde, 2010; Kawase, 2015; Jiang and Hyland, 2016; Carrió-Pastor, 2016). Political talk, though interesting from the point of view of language use to negotiate the presentation of a self that engenders belief and garners the electoral support, remains largely unexplored from a metadiscoursal viewpoint (see, however, Ilie's (2003) study of oral metadiscourse in parliamentary debates, although her understanding of the term metadiscourse is somewhat different from that of Hyland's (2005) interpersonal approach and does not include explicit references to the use of self-mentions as a distinctive rhetorical strategy).

Similarly, the term self-mention and its categorization into different rhetorical roles (or discourse functions) is typically found in studies of self-representation which focus mainly on academic genres such as research articles (e.g., Hyland, 2001; Mur-Dueñas, 2007; Karahan, 2013; Hobbs, 2014; McGrath, 2016), student theses (e.g., Soler-Monreal, 2015), and student oral presentations (e.g., Zareva, 2013). Most of these taxonomies of self-representation in academic discourse are based on Ivanic's (1998) proposal of a continuum of Is showing the degree of power wielded by the author presence through the use of the first person pronoun (e.g., Tang and John, 1999; Hyland, 2002; Martin, 2004; Harwood, 2005; Starfield and Ravelli, 2006; Sheldon, 2009). Yet since all these studies gravitate around the dynamics of authority and self-projection onto academic genres, an alternative framework needs to be adopted which explores different kinds of self- 
mentions and the ethos they convey in light of a different generic context (i.e., the political debate). Also, other contextual variables such as the persona, the prediscursive ethos (or public image of the presidential candidates before the debate), and the degree of intimacy (or pathos) developed with the audience must be considered as well (Cherry, 1998; Maingueneau, 1999, 2002, 2007; Amossy, 2000, 2001, 2010; Charandeau, 2001; Roitman, 2014).

With this in mind, the aim of this paper is to analyze how a credible representation of self (or ethos) is established in political discourse by comparing the employment and distribution of the self-mentions used by the Democratic ticket made up by Hillary Clinton and Tim Kaine and the Republican ticket formed by Donald Trump and Mike Pence during the debates held for the United States presidential general election of 2016. As both Clinton and Trump were very well-known figures among the American public long before they were even standing as presidential candidates, analyzing the building of a self-representation that suits their purposes can provide us with invaluable insight into the way ethos is negotiated verbally and its interplay with the speakers' prior image anchored in cultural stereotypes (Amossy, 2001, 2010; Maingueneau, 2002). In this vein, the research questions of the study are as follows:

1. What are the most significant differences in the use and distribution of selfmentions within a debate between presidential candidates Clinton and Trump and vice presidential candidates Kaine and Pence?

2. To what extent do the candidates' different uses of self-mentions contribute to the creation of a powerful ethos that enhances the speaker's credibility and appeals to the audience's pathos?

3. What impact do contextual factors such as the genre (i.e., political debate), the personae adopted by the candidates, and prior representations of these same candidates have on the projection of ethos as expressed by self-mentions?

\section{Ethos from a functional perspective: relation text-context}

Although the notion of ethos descends from a rhetorical tradition that traces its roots back to ancient Greece (with Aristotle's Rhetoric (see Kennedy's (1991) translation) being the most detailed and representative account of the ethical argument), it remains a somewhat elusive concept. This is mainly due to the fact that the idea of ethos is handled differently across various contemporary disciplines linked to the study of language and its powerful effects upon audiences (Amossy, 2001). From the sociologists' viewpoint, for instance, ethos can no longer be defined as a discursive phenomenon but rather qualifies as a social entity whose efficacy is drawn from the external status enjoyed by the speaker. In other words, the image of self that makes it easier for audiences to trust an orator is not intrinsically dependent on discourse but instead derives its force from the social position of the orator and, as noted by Bordieu (1991: 109), "the access he [or she] can have to the language of the institution, that is, to the official, orthodox and legitimate speech". For the sociologist, therefore, an authoritative ethos can be achieved only within the logic of social interaction and depending on the institutional position held by the speaker (e.g., university professor, political leader, influential writer) and the power conferred to it by the public.

To the idea of a powerful ethos dependent on the external functions of the speaker, pragmatists and discourse analysts oppose the building of the credibility of the orator within discourse. Ducrot (1984), for example, sees ethos as a discursive entity not to be confused with the empirical subject occupying a social position. There is a clear distinction, according to Ducrot (1984: 199), between the speaker ("locuteur") as the 
subject to whom is attributed the responsibility for the utterance and the empirical author as the one actually producing it. The former is ascribed to the discourse itself, whereas the latter belongs to the outside world. This division results in the difference between what Roitman (2014: 746) calls "the represented $I$ " and "the situated $I "$. Represented Is refer to those uses of the first person pronoun when the speaker is portrayed not as speaker but rather as the subject of the actions, states and events discussed, hence eventually becoming the topic under discussion. Situated Is, by contrast, consist of those first person pronoun uses when the speaker operates as the empirical subject who intrudes into the discourse to comment on it and monitor the progress of the interaction. The interplay between both uses of the pronoun $I$ and its contribution to the construction of an ethos of authority is particularly relevant in political debates where, as Roitman (ibid.) notes, "candidates have to position themselves, be in control, and take and keep the floor". Examples from Roitman (ibid.) are shown below:

(1) Hollande: After this digression, I now come [situated I] on to the right to vote. On the right to vote, it's a position I have been defending [represented I] for years.

(2) Sarkozy: I am not your pupil [represented I]. I will respond to that [situated I] once I have told you what I need to tell you [represented I].

At this point, one can wonder whether a discursive approach to the notion of ethos should not necessarily include the parameters of genre in its account of how speakers build an appropriate self-portrayal that instills trust into their audiences. Maingueneau (2007) does so by connecting the verbal construction of self with the rules and constraints of the communicative situation that frames a discourse. The "enunciation scene", as Maingueneau (2007: 60) refers to it, or communicative framework of a discourse can indeed be regarded as a multilayered phenomenon involving three complementary levels. The overall scene designates the type of discourse selected by the speaker and related to its pragmatic status. Different fields have different genres serving specific purposes (e.g., political discourse includes the election speech, the presidential debate, etc.). The generic scene, subordinated to the overall scene, corresponds to the social and cultural rules governing the chosen genre as a discursive institution. For instance, the presidential debate is a dialogic genre in which its participants take turns to speak, often in a somewhat ritualized manner. Finally, the scenography refers to the various ways in which messages can be delivered to audiences, and the different roles adopted by the speakers in the course of the interaction. In a debate, political candidates can present their utterances in different forms and take various roles depending on the effect sought (e.g., they can portray themselves as experienced politicians using a pedagogic tone, or as trustworthy and family oriented people by means of warmer yet more informal messages). For Maingueneau (2007), any detailed analysis of ethos as a discursive aspect that adds credibility to the speaker's words cannot be performed unless it takes these three layers of the enunciation scene into consideration.

The importance placed on the genre and the scenography in which a discursive presentation of self occurs naturally leads to an emphasis on the audience. By way of example, Amossy (2010) underscores that any ethos is rhetorical (or functional) as it reflects the speakers' conscious or unconscious efforts to gain the confidence of their interlocutors. In order to create a sense of intimacy with these interlocutors, and thus appeal to their pathos (which is the Aristotelian mode of persuasion (Kennedy, 1991) related to the desires and expectations of the public), orators are obliged to adapt themselves and the image they project to the demands of an audience framed within a specific communicative and sociocultural context (Amossy, 2000, 2001, 2010). It is this perspective that Amossy (2001) establishes a link between the sociologists' ethos determined by social and institutional positions and the discursive ethos constructed 
through verbal exchanges and within a generic framework. Although Amossy (2001: 20) states that ethos is a "discursive construction", she also highlights the importance of building a powerful representation of self on collective images and ideas associated with positive qualities within a particular social and cultural community.

Yet these collective representations of value among a given public are not merely derived from the social status enjoyed by the speaker. The public image of the orator intervenes as well. This is especially true for well-known personalities such as political leaders, football players, movie stars, or business moguls. The public knows them through what the media have said about them, and the images created for them often respond to preexistent cultural schemas (or what Amossy (2001: 7) prefers to call "stereotypes"). Stereotyping allows for particular individuals to be perceived and evaluated in a somewhat generalized fashion linked to preexistent collective models (e.g., the successful and philanthropic businessman, the manipulative politician, the gifted yet neurotic artist, etc.). If the stereotype associated with a public figure is evaluated as positive, the image of self projected onto a discourse would be aimed at confirming it. If the stereotype, however, is seen as negative, the orator would try to erase it through a discourse designed to transform it into a schema valuable for the audience. It is in light of these phenomena that a distinction can be drawn between the discursive ethos constructed in and with the discourse and the prediscursive ethos made up of collective representations drawing on familiar stereotypes (Maingueneau, 1999, 2002, 2007; Amossy, 2000, 2001, 2010; Roitman, 2014). The prediscursive ethos precedes the construction of the ethos within the discourse, and indeed contributes to determining the authority of speakers at the moment they take the floor. Nonetheless, the building of an image of self during the course of the interaction has the power to either consolidate or modify the prior representations of the orators, hence assisting them in enhancing their credibility and aligning with audiences. In this study, the notion of ethos will be regarded in a similar light, considering that ethos is constructed discursively and therefore analyzing explicit linguistic expressions signaling the speaker's presence in a given discourse. Yet we support, as Amossy (2010) does, the importance of developing a functional approach that includes the rapport with audiences (pathos) in its description of how speakers build an image of themselves that best suits their purposes. As noted above, this speaker-audience relationship can be described as taking place within a specific generic, social and cultural space. Here, we shall be concerned with analyzing the discursive construction of ethos in presidential debates, taking into account the three levels of the enunciation scene proposed by Maingueneau (2007), as well as the establishment of credibility among audiences and how the institutional position of the candidates, together with their prediscursive ethos attached to cultural stereotypes, affect the speakers' authority at the moment of speaking.

\section{Ethos and persona}

Ethos is not the only term used in discourse analysis to refer to the projection of an image of self onto the discourse. The term persona is also used for describing self-representation at a discursive level, despite the fact that, as Cherry (1998: 385) points out, "there are good historical and conceptual grounds for maintaining a distinction between [ethos and persona]". With its roots in classical rhetoric, ethos concerns the character of speakers and their credibility as re-established through the speech itself. Good sense, good moral character and a concern for the audience are among the elements that, according to Aristotle (Kennedy, 1991), orators need to project onto a discourse to appear credible and persuade audiences. Persona, on the other hand, descends from a literary tradition and, as Cherry (1998: 402) puts it, "provides a way of describing the roles authors create for 
themselves in written [or oral] discourse given their representation of the audience, subject matter, and other elements of context".

Adopting Cherry's (1998) definition of persona, our analysis will examine the relationship between the ethos of the speaker as a discursive construction designed to confer authority upon a speech and the creation of various personae as a discursive strategy designed to align the orator's ethos with its communicative purposes. It could be argued that the different personae adopted by orators during the course of the discourse mainly respond to changes in the form in which messages are delivered (Maingueneau, 2007), which in turn are derived from the various ways in which speakers adapt their selfpresentation to the demands of specific audiences. As a matter of fact, when the prediscursive ethos of a speaker comes into play, adjustments are made to either enhance or restore the orator's credibility by modeling the various personae adopted on collective representations valued by a particular community (Amossy, 2001). Using persona as a cover term for the multiple roles played in a discourse certainly allows for a better understanding of the strategies deployed by speakers in order to adjust their ethos of authority to the constraints of the specific generic and sociocultural situation in which the interaction is embedded.

\section{Ethos from a metadiscoursal perspective: taxonomies of self-mentions}

Just as the concept of ethos has not been passed down unchanged through different disciplines, neither has the notion of metadiscourse been seen in the same light across various analytical frameworks. Some discourse analysts delimit the term to explicit features of textual organization (see e.g., Mauranen, 1993; Ädel, 2006), while others take a broader view that stresses the interactive dimension of texts and includes the ways in which speakers organize their material together with their relationship with their audiences. Hyland's (2005) interpersonal framework of metadiscourse adopts the latter perspective, with its description of metadiscourse as an umbrella term covering "the selfreflective expressions used to negotiate interactional meanings in a text, assisting the writer (or speaker) to express a viewpoint and engage with readers as members of a particular community" (Hyland, 2005: 37). From the interpersonal viewpoint, indeed, metadiscourse and rhetoric are intimately related concepts, as metadiscourse devices can be considered rhetorical devices aimed at forging a bond with audiences and therefore securing persuasion.

Hyland's (2005) interpersonal approach to the concept of metadiscourse results in a taxonomy that draws a distinction between "interactive" and "interactional" resources (Hyland, 2005: 49; see also Thompson and Thetela, 1995; Thompson, 2001). The former are concerned with ways of organizing discourse, whereas the latter consist of those resources employed by speakers to involve their interlocutors in the argument. Among the interactional devices included in this taxonomy, self-mentions constitute a category of their own. They are described as metadiscourse devices which make exclusive reference to the speaker in terms of first person pronouns and possessive adjectives, and also by means of self-citations and other self-referential expressions such as the writer (Hyland, 2001: 211; Hyland, 2005: 53). It is clear from this definition, then, that the projection of an ethos of authority within an interpersonal metadiscoursal framework largely depends on the deployment of self-mentions, as demonstrated by the vast number of taxonomies proposed over the last few decades in order to determine the degree of authoritativeness that speakers and writers invest in their discourse through their use of the first person (e.g., Kuo, 1999; Tang and John, 1999; Hyland, 2002; Martin, 2004; Harwood, 2005; Starfield and Ravelli, 2006; Mur-Dueñas, 2007; Sheldon, 2009). 
As stated in the introductory section of this paper, however, all these classification systems for self-representation in terms of self-mentions are focused on academic registers. For instance, Tang and John (1999) take as a starting point the following statement made by Ivanic (1998: 307) to propose different uses of the first person pronoun in academic student essays: "[t]here is a continuum from not using ' $I$ ' at all, through using 'I' with verbs associated with the process of structuring the writing, to using 'I' in association with the research process, and finally to using 'I' with verbs associated with cognitive acts". The complete list of categories contained in Tang and John's (1999: S29) classification and ranked according to their authorial power is shown in Fig. 1:

1. I as the representative - generic use of the first person plural pronoun we or $u s$ to refer to a larger group of people

2. I as the guide through the essay - concerns the writer's role as a guide during the readers' journey through the text, drawing their attention to points that may be obvious from the examples given in the text

3. I as the architect of the essay - used to organize, structure, and outline the material in the essay

4. I as the recounter of the research process - used to describe the different steps of the research process

5. I as the opinion holder - used to share opinions, beliefs, and attitudes with regard to known information or established facts

6. I as the originator - used to present the author as the creator of new ideas and knowledge claims

\section{Least authoritative}

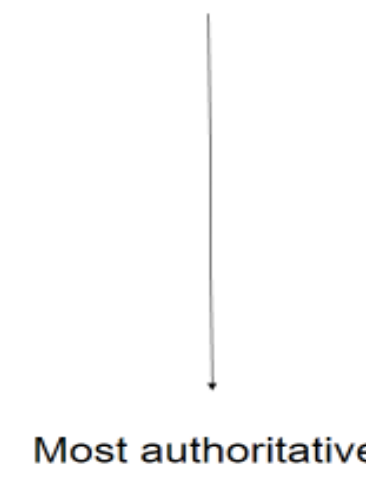

Figure 1 Uses of the first person pronoun in academic writing (Tang and John, 1999: S29)

It needs to be realized that the different categories established in the Tang and John's (1999) typology also encompass inclusive and generic uses of the first person, as illustrated by the following example of the representative I category: "The English language that we have today reflects many centuries of development" (Tang and John, 1999: S27). This marks a significant departure from Hyland's (2005) interpersonal model of metadiscourse, in which inclusive and generic first person uses fall into the category of "engagement markers" (Hyland, 2005: 53), and only exclusive uses of the first person are coded as self-mentions.

Other taxonomies of self-projection in academic genres, by contrast, do maintain the distinction between inclusive and exclusive pronominal uses, either by dividing them into different types of authorial presence (e.g., Martin, 2004), or by excluding them from their classification systems altogether (e.g., Hyland, 2002; Mur-Dueñas, 2007). For example, Hyland (2002) develops the Tang and John's (1999) taxonomy by identifying five different rhetorical functions of the first person pronouns used in student reports and research articles: expressing self-benefits, stating a goal or purpose, explaining a procedure, elaborating an argument, and stating results or claims. The function of expressing self-benefits, carried out by students to comment on what they personally gained from their projects, is regarded as the least threatening, whereas the function of stating claims, performed by researchers to explicitly foreground their distinctive contributions to the field, is considered to be the most authoritative, and hence the most face-threatening, of the cline of authorial presence associated with the use of the first person in academic texts. All these functions are performed through the use of exclusive personal pronouns, eliminating inclusive and generic uses of the first person from the analysis. 
Outside of academic discourse, nonetheless, no extensive studies have been carried out that investigate different types of self-mentions and the authority they project across different communicative contexts. Taking this into account, we believe it would be particularly interesting to explore the various rhetorical functions of self-mentions in political discourse, especially in campaigning genres such as presidential debates where the persuasive power of the speaker is crucial to woo undecided voters. A dual perspective will be adopted, however, which reintegrates both metadiscoursal and functional approaches to the notion of ethos and its manifestation in speech. When we approach selfrepresentation from a metadiscoursal viewpoint, we assume that the construction of a credible ethos within discourse is connected with the use of whole range of self-referential expressions that Hyland (2005) calls self-mentions (i.e., all exclusive first person pronouns and possessives referred to the speaker, together with self-citations and selfreferential expressions). When we approach self-representation from a functional perspective, we assume that electoral debates belong to a different discourse type and genre, so that contextual factors such as the types of audience addressed, the personae adopted by the political candidates, and the prediscursive ethos of these candidates need to be considered as well (Cherry, 1998; Maingueneau, 2007; Amossy, 2001, 2010; Charandeau, 2001; Roitman, 2014).

In what follows, we try to shed some light on how the projection of an authoritative ethos is accomplished through self-mentions in the 2016 United States presidential election debates. First, we discuss the sociocultural and generic situation in which the debates are embedded, and second we describe the data and methods followed in this study. After this, we finally go on to analyze the debates.

\section{The sociocultural context: the prediscursive ethos of the candidates}

The 2016 presidential election in the United States is particularly relevant in terms of selfrepresentation given the heavily loaded prediscursive ethos of the main contenders for the race. On the one hand, Hillary Clinton was a widely known public figure long before she stood as a Democratic presidential candidate due to her prominent political roles, first, as First Lady of the United States from 1993 to 2001, and second, as Secretary of State from 2009 to 2013. On the other hand, her Republican challenger Donald Trump was also world-famous before entering the presidential race given his long-standing celebrity status as business mogul and television personality since the 1980s. Both candidates had an "exceptionally negative" image of themselves circulating within a vast part of public opinion (Visser et al., 2017: 281), with Clinton being disliked for conforming to the stereotype of an emotionless workaholic who is mainly driven by her political ambitions and hence generates mistrust (Brooks, 2016), and Trump's unpopularity being derived from his adjustment to the role of a self-centered man who is contemptuous of social rules and often resorts to violence (Brooks, 2016; Levingston, 2016). Besides, public scandals such as Clinton's email controversy or Trump's leaked tape comments on women increased their unpopularity with voters against the backdrop of a nation polarized as never before (Wagner, 2016). As a result, their campaign speeches interacted with these prior representations of themselves in different ways, giving rise to various personae in an attempt to adapt themselves to the values of the audience.

Vice presidential candidates Kaine and Pence, by contrast, carried a much less loaded and less negative prediscursive ethos than their presidential counterparts, as shown by their significantly higher approval ratings at the start of the election campaign (Parlapiano, 2016; O’Rourke, 2016). Yet while Democratic Senator Tim Kaine projected an image of ideological moderation that prompted criticism from progressive groups (Wagner, 2016), 
Republican Governor Mike Pence did exactly the opposite, perpetuating the stereotype of the extreme right-wing politician by taking hard-line views on social issues like abortion and religious laws (Burns and Haberman, 2016). Nonetheless, since their public images were much less seriously tarnished than those of the presidential nominees, their speeches were less aimed at defending themselves and more concerned instead with rectifying the prior ethos of their running mates.

\section{The generic context: the structure of presidential debates}

Following Maingueneau's (2007) model of the enunciation scene, we understand that political debates are argumentative texts aimed at convincing audiences, and that their dialogic structure involves, as stated in previous sections, turn-taking in a somewhat ritualized fashion. In the United States, the rules and constraints governing presidential debates are authorized by the two campaign organizations and the Commission on Presidential Debates (CPD). Their generic structure can be described as follows: the standard American debate is a 90-minute encounter divided into six segments of approximately 15 minutes in length (or nine segments of about 10 minutes in length as far as the vice presidential debates are concerned). Each segment addresses topics covering either domestic or foreign affairs, and starts with a two-minute common lead question followed by follow-up questions and facilitated discussion between the two candidates. The questions are at the sole discretion of the moderator, and they usually touch on top issues for voters in the United States such as the economy, immigration, job creation, foreign relations, terrorism, nuclear weapons, race relations, gun policy, and fitness to be president. As previously described, our analysis will address the matter of self-projection within discourse in light of these constraints, in an attempt to capture something of the interpersonal essence of ethos and its adaptation to a particular communicative and social framework.

\section{Data}

Of the four debates (three presidential, one vice presidential) organized by the CPD for the 2016 presidential election, two of them were selected for the analysis. To begin with, we worked with the first presidential debate in which Clinton and Trump participated, held on September 26, 2016 at New York's Hofstra University and moderated by Lester Holt of NBC. The rationale behind the choice was that the first Clinton-Trump match set the record as the most-watched presidential debate in television history, with 84 million viewers across the 13 channels that broadcasted it live (Stelter, 2016). We found it interesting to analyze self-representation using the encounter that drew the largest audience at the time. The other debate included in the analysis was the Kaine-Pence vice presidential encounter, which took place on October 4, 2016 at Virginia's Longwood University. The event was moderated by Elaine Quijano of CBS. This match did not attract as many viewers as the presidential debate (36 million), and was indeed the leastwatched vice presidential argument since the Cheney-Lieberman reunion in 2000 (Weprin, 2016). However, we decided to choose this debate since we wanted to compare the frequency and uses of self-projection between the presidential candidates and their respective running mates.

\section{Method}


For the analysis of the debates in terms of self-representation, we used the transcripts downloaded on July 10, 2018 from the website of The American Presidency Project. ${ }^{1}$ All the titles, Website addresses, dates, and moderators' turns were deleted from the transcripts. Also, the candidates' turns were classified individually, so as to allow interpersonal comparisons among the politicians with regard to their use of selfreferential strategies in the debates. See the data compiled for the study in Table 1:

\begin{tabular}{ccccc}
\hline Text file & File size & Tokens & Types & Sentences \\
\hline 1 $^{\text {st }}$ _PD_CLINTON.txt & 35,188 & 6,381 & 1,347 & 419 \\
1 $^{\text {st_PD_TRUMP.txt }}$ & 46,584 & 8,590 & 1,246 & 743 \\
VPD_KAINE.txt & 45,295 & 7,892 & 1,458 & 596 \\
VPD_PENCE.txt & 45,256 & 7,811 & 1,430 & 500 \\
Overall & 172,323 & 30,674 & 3,130 & 2,258 \\
\hline
\end{tabular}

Table 1 Data compiled for the analysis.

The dataset was analyzed in two steps. First, all instances of first person pronouns and possessives (I, me, my, we, us, our), self-citations, and self-referential expressions such as this ticket or the Democratic Party were searched for across the material using the concordance software WordSmith Tools (7.0). Once all cases were identified, they were examined in the context of their use and the following cases were removed from the study: (1) instances of intertextuality (Blackledge, 2005; Reyes, 2015) where the tokens were not used as a self-reference (e.g., "They sat back probably and said, I can't believe it." [1 ${ }^{\text {st }}$ PD_TRUMP]); (2) cases of speech dysfluencies like false starts and repetitions (e.g., "I think - I think-I think Donald just criticized me for preparing for this debate." [1 ${ }^{\text {st }}$ PD_CLINTON]); and finally (3) occurrences of generic and inclusive first person uses (e.g., "We've seen America's place in the world weakened." [VPD_PENCE]).

Note that instances of generic and inclusive pronominal use are left aside from the analysis since our methodological choice follows, as explained in previous sections, Hyland's (2005) model of interpersonal metadiscourse and his distinction between what he calls self-mentions (i.e., exclusive first person pronouns and possessives), and engagement markers (i.e., inclusive and generic first person uses), with only the former being of interest to our study. ${ }^{2}$ Some difficulties were encountered, however, distinguishing between exclusive and inclusive pronoun uses in the framework of political debates, given the speakers' recurrent identification with multiple addressees including: (1) their opponents in face-to-face interaction (e.g., "Finally, we tonight are on the stage together, Donald Trump and I." [1 ${ }^{\text {st }}$ PD_CLINTON]); (2) their families (e.g., "We trust Hillary Clinton, my wife and I." [VPD_KAINE]); (3) their entrepreneurial partners outside the realm of politics (e.g., "We're just opening up on Pennsylvania Avenue right next to the White House." [1 ${ }^{\text {st }}$ PD_TRUMP]); and (4) the massive audience watching the debate either in the studio or via broadcast media (e.g., "You look at what China is doing to our country in terms of making our product." [1 ${ }^{\text {st }}$ PD_TRUMP]).

All these occurrences of inclusive plural first person uses were eliminated from the study, coding only as self-mentions those cases of plural pronominal use in which orators identify with their ticket in the election (e.g., "All Donald Trump - all Donald Trump and I have said about Social Security is we're going to meet our obligations to our seniors." [VPD_PENCE]), and also when the speakers make explicit reference to the

\footnotetext{
See Internet archive: https://www.presidency.ucsb.edu/documents/app-categories/elections-andtransitions/debates [Last accessed: 05/05/2019]

${ }^{2}$ We recognize, however, the potential of inclusive uses of the first person to rhetorically persuade audiences, so that this could be the subject for future research in this area (see the conclusive section of this paper).
} 
whole political organization represented by them (e.g., "But I like to remember what Michelle Obama said in her amazing speech at our Democratic National Convention." [1 ${ }^{\text {st }}$ PD_CLINTON]).

Having completed the quantitative collection of self-mention features, the second and final step was to manually examine each instance in the wider context in which it was used with the aim of determining its rhetorical function. In assigning the functional categories, we built on the idea of a continuum of self-mentions similar to the ones proposed by Tang and John (1999), Hyland (2002) and others in academic discourse, yet showing the degree of power wielded by the orator's self-projection in a political debate. We therefore had to make some adjustments in order to conform to the constraints of the generic and social situation framing the debates, as will be detailed later. In order to double check the functional analysis of the categories established in our study, we also used a specific tool designed to detect and analyze metadiscoursal strategies, METOOL. ${ }^{3}$

\section{Results}

\subsection{Frequency of use and distribution of self-mention features}

The results in Table 2 reveal that an average of thirty in every thousand words (i.e., three in every hundred words) uttered by the candidates during the debates were self-mention markers. ${ }^{4}$ As can be observed, the pronoun $I$ was the most common self-referential form overall (20.6 occurrences per 1,000 words), and first person singular pronouns comprised $81.6 \%$ of the total. Regarding plural tokens, the most frequently used feature was by far the subject pronoun we ( 3.0 vs. 0.1 and 0.2 occurrences per 1,000 words), and first person plural pronouns represented $10.8 \%$ of the total. Finally, citations and other self-referential expressions such as this ticket or Democrats were much less common in the debates (especially the latter with 0.2 occurrences per 1,000 words), and only scored $7.5 \%$ of the total.

\begin{tabular}{cccccccccc}
\hline Text file & I & Me & My & We & Us & Our & Citation & Other & Total \\
\hline 1 $^{\text {st }}$ PD_CLINTON.txt & 21.0 & 0.9 & 0.9 & 1.4 & 0.0 & 0.2 & 3.0 & 0.2 & 27.6 \\
$1^{\text {st }}$ _PD_TRUMP.txt & 27.9 & 3.6 & 2.0 & 0.5 & 0.0 & 0.0 & 3.7 & 0.1 & 37.8 \\
VPD_KAINE.txt & 12.9 & 2.0 & 1.5 & 5.8 & 0.0 & 0.3 & 0.3 & 0.3 & 23.1 \\
VPD_PENCE.txt & 20.1 & 2.0 & 3.7 & 4.2 & 0.3 & 0.3 & 1,4 & 0.4 & 32.4 \\
Overall & 20.6 & 2.2 & 2.1 & 3.0 & 0.1 & 0.2 & 2.1 & 0.2 & 30.5 \\
\hline
\end{tabular}

Table 2. Frequency of self-mention forms per speaker and debate (per 1,000 words)

Interestingly, there seems to be a correlation between the frequency of use of self-mention strategies in the debates and the political affiliation of its participants. Figure 2 gives an impression of this comparison by showing the use of exclusive first person pronouns, self-citations, and other self-referential tokens by each of the candidates involved. As can be seen, Trump deployed a far larger number of self-mentions (325 occurrences) than Clinton (176 occurrences) in the debates, scoring significantly higher in his employment of personal pronouns for self-reference (292 vs. 156 occurrences). The same goes for Trump's running mate Pence and his rival, Clinton's companion Kaine. The difference between Pence and Kaine in terms of explicit self-representation, however, is smaller regarding not only the overall use of self-mention features (253 vs. 182 occurrences) but

\footnotetext{
${ }^{3}$ METOOL is a software concordance program designed to detect, tag and analyze metadiscourse strategies which is currently being developed with research funding from the Spanish government (ReferenceFFI2016-77941-P).

${ }^{4}$ These $^{\mathrm{o}}$ figures were normalized to occurrences per 1,000 words to facilitate comparison among the candidates.
} 
also their deployment of personal pronouns (239 vs. 178 occurrences). Still, it remains clear that the Republican ticket of Trump and Pence used considerably more self-mention items to present their arguments than their Democratic counterparts.

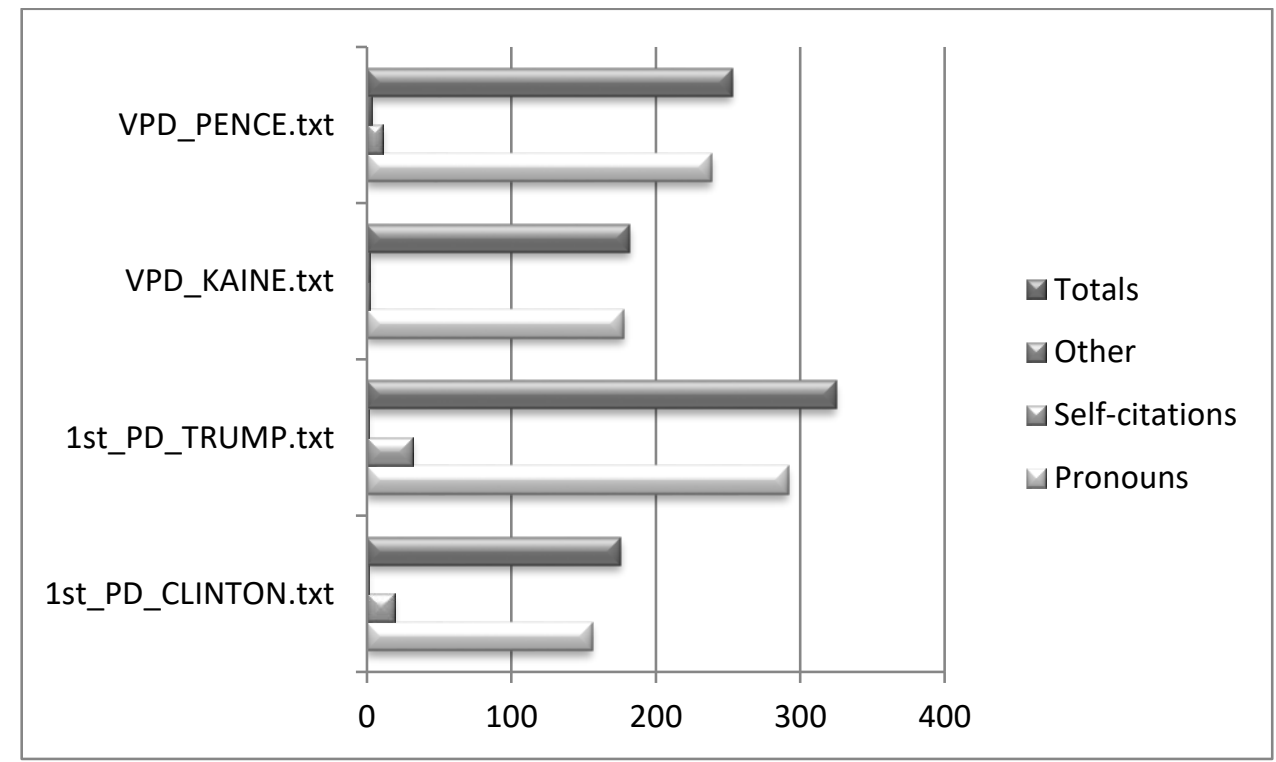

Figure 2. Occurrences of self-mention per speaker

With regard to the distribution of self-mention tokens within the debates, what the concordance analysis revealed is that the most frequently used forms (i.e., pronominal singular choices such as $I$ or $m e$ ) tend to appear, first, in the most dialogic sequences when speakers try to monitor the interaction and defend themselves from their opponents' attacks and second, in those monological sequences in which the candidates talk especially about: (1) their opinions and beliefs, signaled by the use of the verbs think, believe, support, and so on; (2) their political plans and policies, expressed through the use of verbs in the future tense (will, be going to), or expressions depicting promises and intentions (e.g., promise, want, determined, plan); (3) their political and personal achievements, indicated by the overtly self-promotional tone of the utterances (e.g., "So I know how to really work to get new jobs and to get exports that helped to create more new jobs." [1 ${ }^{\text {st }}$ PD_CLINTON]). Yet while Clinton usually deploys more self-mentions when discussing her views, her plans as a contender for the presidency and her past political experiences, Trump concentrates his efforts on controlling the interaction through the use of $I s$ and also on speaking in the first person about his expertise as a successful businessman beyond the realm of politics. In the following section, we examine more thoroughly the different rhetorical functions associated with the use of these self-mentions by each candidate, shedding some extra light on the distribution of self-referential resources across the data.

\subsection{Self-mentions and their discourse functions}

The results of the contrastive analysis of the self-mention functions most frequently associated with each candidate are shown in Table 3.

\begin{tabular}{ccccc}
\hline & CLINTON & TRUMP & KAINE & PENCE \\
\hline Situated speaker & 1.6 & 8.0 & 4.3 & 8.1 \\
\hline Evidential & 3.0 & 3.0 & 0.8 & 2.2 \\
\hline Opinion-holder & 7.5 & 5.2 & 3.7 & 3.8 \\
\hline
\end{tabular}




\begin{tabular}{ccccc}
\hline Policy-maker & 3.4 & 3.0 & 4.9 & 5.1 \\
\hline Individual & 1.6 & 9.5 & 3.2 & 5.9 \\
\hline Political & 7.7 & 5.4 & 6.5 & 6.3 \\
\hline
\end{tabular}

Table 3. Frequency of self-mention functions per speaker (per 1,000 words)

In categorizing the various functions of the self-mentions employed by each speaker, we took as our starting point the Roitman's (2014) distinction between represented Is and situated Is in political debates. At the same time, our objective was also to establish a cline of authoritative ethos similar to the ones displayed by the classification systems for self-mentions in academic genres. Thus understood, the different types of self-mentions that we put forward to examine the degree of authority projected onto presidential debates can be described as follows:

\section{I as the situated speaker in the debate}

This function concerns the candidates' awareness of the audience of the debate as well as their desire to control, monitor and evaluate the impact of their messages in the course of the interaction. The debaters' purpose here is mainly interactive, in Hyland's (2005) terms, since they focus on ways of organizing discourse, rather than experience. Also, it can be considered to be in line with what Roiman (2014) refers to as the situated I, assisting speakers in positioning themselves within the communicative situation to comment on it and dominate its progress. Orators here refer to themselves primarily as speakers (discourse-internal) rather than politicians or individuals (discourse-external). Using Halliday's (1994) terminology, this category often appears with verbal process verbs such as say, tell, ask, respond, finish (e.g., a sentence), and talk:

(1) Now, let me say this, it is absolutely the case... (1 $1_{-}^{\text {st }}$ PD_CLINTON)

(2) So I will tell you this. We have to do a much better job at keeping our jobs. ( $1^{\text {st }}$ PD_TRUMP)

(3) Let me talk about the things that Governor Pence doesn't want to acknowledge, Elaine. (VPD_Kaine)

(4) They have not - Elaine, let me finish a sentence. They have not renounced their nuclear ambitions. (VPD_Pence)

Even though the categories associated with the representation of self as a discourseinternal entity are regarded as carrying much less authoritative power in academic genres (see figure 1 in Section 2 of this paper), the same does not apply in political debates in which speakers also exert authority by trying to control the interaction and dominate the discourse. As seen in table 3 above, Trump and Pence exercised much more control through the use of this discursive function than their Democratic adversaries, something which can be regarded as a result of their desire to disguise themselves with the persona of the right-wing politician who tells the truth in spite of its consequences. Nevertheless, the authority projected through this function belongs to a different type from that of the following functions, which are, as we will see below, more connected with the presentation of self in the real world (i.e., the represented I in Roitman's (2014) model).

\section{Evidential I}

With this function the candidates shift from referring to themselves as speakers in the world of discourse to referring to themselves as politicians in the real world. Yet the focus is not still on the debaters' stance towards particular issues - rather it is on those pieces of information they choose to foreground to provide evidence for their arguments. By stressing their first-hand knowledge of some facts, or quoting someone else's words 
(usually bringing the voice of well-respected figures into the debate), the candidates can present themselves as well-informed politicians committed to developing evidencebased, responsive policies and strategies:

(1) I've heard from so many of you about the difficult choices you face and the stresses that you're under. So let's have paid family leave, earned sick days. $\left(1^{\text {st }}\right.$ PD_CLINTON)

(2) But I will tell you, I've been all over. And I've met some of the greatest people I'll ever meet within these communities. ( $3^{\text {rd }}$ PD_TRUMP)

(3) And I'm really amazed, Elaine, as I talk to Republican senators, how well they regard and respect Hillary Clinton. (VPD_KAINE)

(4) I was in Washington, D.C., on 9/11. I saw the clouds of smoke rise from the Pentagon. (VPD_PENCE)

As seen above, this usage of the first person pronoun generally co-occurs with verbs signaling mental processes of perception (such as hear, see, look, and so on), and material process verbs describing experiences and day-to-day responsibilities of the candidates (such as visit, travel, meet, and so on).

\section{I as the opinion-holder}

This category is often realized through the pairing of first person pronouns with verbs depicting mental processes of cognition such as think, believe, feel, agree, and so on (Halliday, 1994). Politicians generally share their opinions, beliefs and attitudes (for example, by expressing agreement, disagreement or interest) in an overtly rhetorical manner, putting particular emphasis on their own positions (or those of the party ticket they represent) in order to distance themselves from the opponent. This can be an explanation for the frequent co-occurrence of the first person pronoun with what Hyland (2005) calls boosters (e.g., fully, really, strongly, truly), used by the candidates to emphasize the strength of their certainty, and attitude markers (e.g., disgraceful), conveying the debaters' affective, rather than epistemic, attitude to propositions:

(1) And I believe strongly that commonsense gun safety measures would assist us. $\left(1^{\text {st }}\right.$ PD_CLINTON $)$

(2) I think what the FBI did and what the Department of Justice did, including meeting with her husband, the attorney general, in the back of an airplane on the tarmac in Arizona, I think it's disgraceful. (1 ${ }^{\text {st }}$ PD_TRUMP)

(3) But we really feel like you should live fully and with enthusiasm the commands of your faith. (VPD_KAINE)

(4) We truly do believe that law enforcement is not a force for racism or division in our country. (VPD_PENCE)

\section{I as the policy-maker}

The function of policy-maker implies the candidates' presentation and discussion of the policies they promise to support when elected. It represents a further step in the direction of power wielded by the speaker's presence since the politician moves from sharing a view (or attitude) to highlighting what he or she is going to do based on that attitude. This category foregrounds the politician's role in providing solutions to the citizens' problems in an explicit way:

(1) I want us to invest in you. I want us to invest in your future. ( ${ }^{\text {st }}$ PD_CLINTON) 
(2) I'm going to cut taxes big league, and you're going to raise taxes big league, end of story. ( $1^{\text {st }}$ PD_TRUMP)

(3) And, fifth, we have a tax plan that targets tax relief to middle- class individuals and small businesses and asks those at the very top who've benefited as we've come out of recession to pay more. (VPD_KAINE)

(4) They're going to raise your taxes. We're going to cut your taxes. (VPD_PENCE)

As can be inferred from the previous examples, this role is usually realized through the co-occurrence of the first person pronoun with material process verbs such as defend, build, cut, vote, and so on (Halliday, 1994), used in the future tense, or introduced by verbs depicting promises and intentions (e.g., promise, want, hope, plan, intend, and so on). Alternatively, the category can also be signaled by the use of verbs (e.g., propose), adjectives (e.g., determined), and nouns (e.g., plan) conveying the same or similar meanings (see example (15) above).

\section{Reflexive I}

The reflexive I in political discourse draws attention to the speaker' autobiographical self. But it can be further divided into two sub-categories: the individual self, which is the role the speakers assume to share their thoughts, feelings, and events from their private, personal life that they feel relevant to the issues raised during the debate and the political self, which highlights the speaker's past or present achievements, inner reflections, and experiences as a politician and/or candidate for the election. In the context of a presidential debate, this function is indicated by co-textual clues that locate the speaker as subject and object of the discussion simultaneously:

(1) When I was secretary of state, we actually increased American exports globally 30 percent. We increased them to China 50 percent. So I know how to really work to get new jobs and to get exports that helped to create more new jobs. ( $1^{\text {st }}$ PD_CLINTON)

(2) I do want to say that I was just endorsed - and more are coming next week-it will be over 200 admirals, many of them here-admirals and generals endorsed $m e$ to lead this country. ( $1_{\text {st }}^{\text {st }}$ PD_TRUMP)

(3) And that's what I bring to the ticket, that experience having served at all levels of government. But my primary role is to be Hillary Clinton's right-hand person and strong supporter as she puts together the most historic administration possible. (VPD_KAINE)

This particular category is unique in the overtly self-promotional tone of the speech, with speakers speaking about themselves to boast about their political expertise and achievements. When referring to other professional experiences (beyond the field of politics) and aspects of their personal lives, the aim is to convince audiences of the credibility of the individual behind the first person pronoun as well:

(1) I don't buy that. I have a different experience. My father was a small-businessman. He worked really hard. ( $1^{\text {st }}$ PD_CLINTON).

(2) But I take advantage of the laws of the nation because I'm running a company. My obligation right now is to do well for myself, my family, my employees, for my companies. And that's what $I$ do. $\left(1^{\text {st }}\right.$ PD_TRUMP)

(3) I was also raised in a wonderful family of faith. It was a church on Sunday morning and grace before dinner. (VPD_PENCE)

As can be observed, Clinton used the first person pronoun mainly to emphasize her political expertise and to express her opinions and attitudes towards the topics discussed 
during the debate. She put far less emphasis on sharing intimate details of her personal life, even though there were instances from her statements in which both the personal and the political were intertwined in some way:

(1) I think my husband did a pretty good job in the 1990s. I think a lot about what worked and how we can make it work again... ( $1^{\text {st }}$ PD_CLINTON)

This is understandable given their prediscursive ethos as an industrious, career-oriented woman and also considering Trump's harsh criticisms against Bill Clinton's administration and the political class in general. Logically, Clinton felt she should defend her husband's legacy as president as well as the record of the political party they represent. Here are more examples of her use of exclusive pronouns to highlight not only her own achievements but also those of her colleagues as far as foreign policies are concerned:

(2) With respect to Iran, when I became secretary of state, Iran was weeks away from having enough nuclear material to form a bomb. They had mastered the nuclear fuel cycle under the Bush administration. They had built covert facilities. They had stocked them with centrifuges that were whirling away. And we had sanctioned them. I voted for every sanction against Iran when I was in the Senate, but it wasn't enough. So I spent a year-and-a-half putting together a coalition that included Russia and China to impose the toughest sanctions on Iran. And we did drive them to the negotiating table. And my successor, John Kerry, and President Obama got a deal that put a lid on Iran's nuclear program without firing a single shot. That's diplomacy. That's coalition-building. That's working with other nations.

Unlike Clinton, Trump relied more on his prior ethos linked to his long professional record in the corporate world to convince audiences that he is the best candidate to fix the economy of the United States. This role was predominantly realized by the use of the singular subject pronoun $I$ as well as the possessive determiner $m y$ followed by nouns related to personal and business-related experiences (e.g., my father, my family, my son, my companies, my employees):

(3) Well, for one thing — and before we start on that — my father gave me a very small loan in 1975, and I built it into a company that's worth many, many billions of dollars, with some of the greatest assets in the world, and I say that only because that's the kind of thinking that our country needs.

As for the vice presidential candidates, both Kaine and Pence talked primarily about their long history of involvement in politics. In the case of Kaine, he usually identified himself with Hillary Clinton at the political level:

(4) She [Clinton] has a track record of working across the aisle to make things happen. And, you know, Elaine, I have the same track record. I was a governor of Virginia with two Republican houses. And in the Senate, I have good working relationships across the aisle.

On the other hand, Pence's use of the first person pronoun was related to the organization of speech, first, and an emphasis on his political expertise, second. Example (27) illustrates the need to introduce new topics and underline the importance of his statements:

(5) Well, first, let me say, I appreciated the "you're hired," "you're fired" thing, Senator. 
Example (28) illustrates the use of self-reference to boast about his own record as a successful Governor of his state:

(6) I mean, I'm very proud of the fact that - I come from a state that works. The state of Indiana has balanced budgets. We cut taxes, we've made record investments in education and in infrastructure, and I still finish my term with $\$ 2$ billion in the bank.

\section{Conclusions}

Quantitatively speaking, these findings represent a major departure from previous analyses of self-projection in academic genres which also applied Hyland's (2005) interpersonal model of metadiscourse to their investigation of self-mention strategies (see e.g., Hyland, 2001; Mur-Dueñas, 2007). A much higher degree of explicit self-reference in presidential debates is observed which can be attributed, first, to the argumentative nature of political discourse (i.e., the overall scene in Maingueneau's (2007) terms), and second, to the interactive structure of the electoral debate (i.e., the generic scene), which requires explicit self-positioning on the part of the speaker in terms of discourse management and turn-taking.

The greater use of self-mentions by the Republican ticket of Trump and Pence could perhaps be explained considering the social context in which the debates were embedded. First is the fact that, generally speaking, political challengers need to put extra effort into constructing a powerful ethos within discourse as a means to defeat the candidates of the incumbent party. Second, the controversy surrounding this particular election, especially as regards Trump's self-centered image and anti-establishment rhetoric, most surely led both Trump and his running mate to consolidate the potential president's prediscursive ethos as an outsider by means of self-referential tokens.

In qualitative terms, the results demonstrate that Clinton and Trump use different rhetorical strategies to gain credibility and win votes, with the former foregrounding her political career and the latter centering on his personal side and business achievements. This seems to be in line with the prior ethos that they carried before the debates, and shows that they opted for reinforcing the stereotypes associated with their figures with the aim of enhancing their credibility among voters. The vice-presidential candidates engage in similar patterns in that they also emphasize their own professional expertise and suitability for the position they are hoping to achieve. But while Kaine put more emphasis on the content, Pence also paid attention to the formal structure of his speeches to highlight those aspects he considered relevant for his campaigning purposes.

\section{References}

Ädel, A., 2006. Metadiscourse in L1 and L2 English. Amsterdam, John Benjamins. Amossy, R., 2010. La présentation de soi: Ethos et identité verbale [Self-presentation: Ethos and verbal identity]. Paris, Presses Universitaires de France.

Boyd, M. S. 2013. Reframing the American dream: Conceptual metaphor and personal pronouns in the 2008 US presidential debates. In P. Cap \& U. Okulska (eds.), Analyzing Genres in Political Communication. Theory and practice (pp. 297320). Amsterdam: John Benjamins. DOI https://doi.org/10.1075/dapsac.50.12boy

Bull, P., Fetzer, A., 2006. Who are we and who are you? The strategic use of forms of address in political interviews. Text \& Talk 26(1), 3-37.

Burns, A. and Haberman, M., 2016. How Donald Trump Finally Settled on Mike Pence. Available at The New York Times. Available at https://www.nytimes.com 
/2016/07/16/us/politics/mike-pence-donald-trump-vice-president.html?mcubz=0 [Accessed 06/04/2018]

Carrió-Pastor, M. L. 2016. A contrastive study of interactive metadiscourse in academic papers written in English and in Spanish. In Francisco Alonso Almeida, Laura Cruz García \& Víctor González Ruiz (Eds.), Corpus-based studies on language varieties. Bern, Peter Lang.

Carrió-Pastor, M. L. 2019. Authorial engagement in business emails. A cross-cultural analysis of attitude and engagement markers. In C. Sancho Guinda (Ed.), Engagement in Professional Genres: Deference and disclosure. Amsterdam, John Benjamins, pp. 47-66.

Chilton, P., 2004. Analysing political discourse: Theory and practice. London/New York, Routledge.

Dafouz-Milne, E., 2008. The pragmatic role of textual and interpersonal metadiscourse markers in the construction and attainment of persuasion: a cross-linguistic study of newspaper. Journal of Pragmatics 40(1), 95-113.

Davis, C.B., 2013. An inconvenient vote: Hillary Clinton's Iraq war image repair debate strategies and their implications for representative democracy. Public Relations Review 39(4), 315-319.

De Fina, A. 1995. Pronominal choice, identity, and solidarity in political discourse. TextInterdisciplinary Journal for the Study of Discourse, 15(3), 379-410.

Fetzer, A. \& Bull, P. 2008. "Well, I answer it by simply inviting you to look at the evidence". The strategic use of pronouns in political interviews. Journal of Language and Politics, 7(2), 271-289.

García-Pastor, M.D., 2008. Political campaign debates as zero-sum games: Impoliteness and power in candidates' exchanges. In: Bousfield, D., Locher, M. A. (Eds.). Impoliteness in language: Studies on its interplay with power in theory and practice (Vol. 21). Berlin/New York, Mouton de Gruyter, pp. 100-123.

Gillaerts, P., Van de Velde, F., 2010. Interactional metadiscourse in research article abstracts. Journal of English for Academic Purposes 9(2), 128-139.

Harwood, N., 2005. 'Nowhere has anyone attempted... In this article I aim to do just that': A corpus-based study of self-promotional I and we in academic writing across four disciplines. Journal of Pragmatics 37(8), 1207-1231.

Hobbs, V., 2014. Accounting for the great divide: Features of clarity in analytic philosophy journal articles. Journal of English for Academic Purposes 15, 27-36.

Hyland, K., 2001. Humble servants of the discipline? Self-mention in research articles. English for Specific Purposes 20(3), 207-226.

Hyland, K., 2002. Authority and invisibility: authorial identity in academic writing. Journal of Pragmatics 34, 1091-1112.

Hyland, K., 2005. Metadiscourse. London, Continuum.

Hyland, K., 2017. Metadiscourse. What is it and where is it going? Journal of Pragmatics $113,16-29$.

Hyland, K., Tse, P., 2004. Metadiscourse in scholastic writing: a reappraisal. Applied Linguistics 25(2), 156-177.

Ivanova, A. (2016). Deixis and its role in defining rhetorical space. Revista Signos. Estudios de Lingüística, 49(92), 329-349.

Jiang, F.K., Hyland, K., 2016. Nouns and academic interactions: a neglected feature of metadiscourse. Applied Linguistics. Available at http://dx.doi.org/10.1093/ applin/amw023 [Accessed 05/06/2018]

Karahan, P., 2013. Self-mention in scientific articles written by Turkish and non-Turkish authors. Procedia: Social and Behavioral Sciences 70, 305-322. 
Kawase, T., 2015. Metadiscourse in the introductions of $\mathrm{PhD}$ theses and research articles. Journal of English for Academic Purposes 20, 114-124.

Kennedy, G. A., 1991. Aristotle, on rhetoric: A theory of civic discourse. Oxford University Press, New York.

Leudar, I., Marsland, V., \& Nekvapil, J. 2004. On membership categorization:'us', 'them'and 'doing violence'in political discourse. Discourse \& Society, 15(2-3), 243-266.

Littleton, C. and Schwindt, O. 2016. Trump-Clinton Second Debate Ratings Fall 21\% With 66.5 Million Viewers. Variety. Available at https://variety.com /2016/tv/news/trump-clinton-debate-2-ratings-drop-1201883637/[Accessed $10 / 12 / 2018]$

Maingueneau, D., 1999. Ethos, scénographie, incorporation [Ethos, scenography, incorporation]. In: Amossy R (ed.) Images de soi dans le discours, La construction de l'ethos. Lausanne: Delachaux \& Niestlé, pp. 75-101.

Maingueneau D (2002) L'ethos, de la rhétorique à l'analyse du discours [Ethos, from rhetoric to discourse analysis]. Available at: http://dominique.maingueneau.pagesperso-orange.fr/intro_company.html [Accessed 19/3/2019].

Martín, P. M., 2004. Personal attribution in English and Spanish scientific texts. BELLS: Barcelona English language and literature studies, 12.

McGrath, L., 2016. Self-mentions in anthropology and history research articles: Variation between and within disciplines. Journal of English for Academic Purposes 21, 8698.

Moya, P. and Carrió-Pastor, M. L. 2018c. La atenuación en los comentarios sobre las noticias digitales en periódicos de España y Chile. Onomázein. Revista de lingüística, filología y traducción, 40, 56-76.

Moya, P. and Carrió-Pastor, M. L. 2018b. Análisis comparativo de los marcadores de compromiso en los comentarios sobre noticias digitales en España y Chile. Onomázein. Revista de lingüística, filología y traducción, Special issue, 4, $26-48$.

Moya, P. and Carrió-Pastor, M. L., 2018a. Estrategias de intensificación en los comentarios digitales sobre noticias. Spanish in Context, 15(3), 369-391.

Mur-Dueñas, P., 2007. "I/we focus on...": A cross-cultural analysis of self-mentions in business management research articles. Journal of English for Academic Purposes 6, 143-162.

Murphy, J. J., Katula, R.A. and Hoppmann, M., 2014. A synoptic history of classical rhetoric. New York/London,Routledge.

O'Rourke, A., 2016. What Is Tim Kaine's Approval Rating? Hillary Clinton's Vice President Pick Has a Solid History. Bustle. Available at https://www.bustle.com/articles/174373-what-is-tim-kaines-approval-rating-hillaryclintons-vice-president-pick-has-a-solid-history [Accessed 10/05/2018]

Pappas, S., 2016. Polarizing Politics: 5 Reasons the 2016 Election Feels So Personal. Live Science. Available at https://www.livescience.com/56707-why-presidential-electionfeels-so-personal.html [Accessed 07/04/2018]

Parlapiano, A., 2016. Pence Ranks Low in Approval, but Not as Low as Trump and Clinton. The New York Times. Available at https://www.nytimes.com/interactive/2016/07/14/us/politics/mike-pence-approvalrating-governors.html?mcubz=0 [accessed 19/04/2018]

Pavlidou, T. S. (Ed.). 2014. Constructing Collectivity: 'We' across languages and contexts. Amsterdam: John Benjamins.

Proctor, K., Su, L., W., 2011. The 1st person plural in political discourse - American politicians in interviews and in a debate. Journal of Pragmatics 43, 3251-3266. 
Rappeport, A., 2016. Who Won the Debate? Hillary Clinton, the 'Nasty Woman'. The New York Times. Available at https://www.nytimes.com/2016/10/21/us/ politics/whowon-the-third-debate.html?mcubz=0 [Accessed 19/05/2018]

Reisigl, M., 2008. Rhetoric of political speeches. In R. Wodak, and V. Koller, (Eds.), Handbook of communication in the public sphere. Berlin/New York, Mouton de Gruyter, pp. 243-269.

Reyes, A., 2015. Building intimacy through linguistic choices, text structure and voices in political discourse. Language \& Communication 43, 58-71.

Roitman, M., 2014. Presidential candidates' ethos of credibility: The case of the presidential pronoun I in the 2012 Hollande-Sarkozy debate. Discourse \& Society, 25(6), 741-765.

Sacks, H., 1995. Lectures on conversation. Oxford/Cambridge,Blackwell.

Sheldon, E., 2009. From one I to another: Discursive construction of self-representation in English and Castilian Spanish research articles. English for Specific Purposes 28(4), 251-265.

Starfield, S. and Ravelli, L. J., 2006. "The writing of this thesis was a process that I could not explore with the positivistic detachment of the classical sociologist": Self and structure in New Humanities research theses. Journal of English for Academic Purposes 5(3), 222-243.

Stelter, B. 2016. Debate breaks record as most-watched in U.S. history. CNN Business Available at https://money.cnn.com/2016/09/27/media/debate-ratings-recordviewership/index.html [Accessed 15/12/2018]

Tabakowska, E., 2002. The regime of the other. In A. Duskaz, (Ed.), Us and Others: Social Identities across Languages, Discourses and Cultures. Amsterdam/Philadephia, John Benjamins.

Tang, R., John, S., 1999. The 'I' in identity: Exploring writer identity in student academic writing through the first person pronoun. English for Specific Purposes 18, S23S39.

Vasquez, C., 2015. 'Don't Even Get Me Started...'”: interactive metadiscourse in online consumer reviews. In Darics, E. (Ed.), Digital Business Discourse. London, Palgrave, pp.19-39.

Visser, B.A., Book, A.S., Volk, A.A., 2017. Is Hillary dishonest and Donald narcissistic? A HEXACO analysis of the presidential candidates' public personas. Personality and Individual Differences 106, 281-286.

Wagner, J., 2016. Kaine's VP pick greeted by blowback from progressive groups. The Washington Post. Available at https://www.washingtonpost.com/politics/kaines-vppick-greeted-by-blowback-from-progressive-groups/2016/07/22/b81e51ce-5067-11e6a7d8-13d06b37f256_story.html?utm_term=.961a2dd5d5b4 [Accessed 9/07/2018]

Weprin, D. I. (2016). Assemblyman David I. Weprin Reports to the Community Summer 2016. Available at https://nyassembly.gov/mem/David-IWeprin/story/71479 [Accessed 15/12/2018]

Wilson, J., 1990. Politically speaking. The pragmatic analysis of political language. Oxford/Cambridge/Massachusetts, Blackwell.

Zareva, A., 2013. Self-mention and the projection of multiple identity roles in TESOL graduate student presentations: The influence of the written academic genres. English for Specific Purposes 32(2), 72-83.

Zupnik, Y. J. (1994). A pragmatic analysis of the use of person deixis in political discourse. Journal of Pragmatics, 21(4), 339-383. 